\title{
Pertumbuhan dan Produksi Kedelai Hitam (Glycine max L. Merill) pada Berbagai Jenis Pupuk Kandang dan Konsentrasi Plant Growth Promoting Rhizobacteria
}

\section{Growth and Production of Black Soybean (Glycine max L. Merill) on Various Types of Manure and Concentration of Plant Growth-Promoting Rhizobacteria}

\author{
Murtinah $^{1 *}$, Eny Fuskhah ${ }^{2}$, Adriani Darmawati ${ }^{2}$ \\ ${ }^{1}$ Program Studi Agroteknologi, Departemen Pertanian, Fakultas Peternakan dan Pertanian \\ Universitas Diponegoro \\ ${ }^{2}$ Departemen Pertanian, Fakultas Peternakan dan Pertanian, Universitas Diponegoro \\ *Email: murtinahtina67@gmail.com
}

Diterima 29 Agustus 2019 / Disetujui 22 Februari 2020

\begin{abstract}
ABSTRAK
Penelitian ini bertujuan untuk mengkaji pengaruh penggunaan jenis pupuk kandang dan berbagai konsentrasi plant growth promoting rhizobacteria (PGPR) terhadap pertumbuhan dan produksi kedelai hitam (Glycine $\max$ L. Merill). Rancangan percobaan yang digunakan adalah rancangan acak lengkap pola faktorial. Faktor pertama adalah jenis pupuk kandang (tanpa pupuk, pupuk kandang ayam dan pupuk kandang kambing) dan faktor kedua adalah konsentrasi PGPR (PGPR komersial $5 \mathrm{ml} / \mathrm{l}$ air, $0 \mathrm{ml} / \mathrm{l}$ air, $5 \mathrm{ml} / \mathrm{l}$ air, 12,5 ml/1 air, dan 20 $\mathrm{ml} / \mathrm{l}$ air). Parameter pertumbuhan yang diamati meliputi tinggi tanaman dan jumlah daun. Parameter produksi yang diamati yaitu jumlah polong, berat polong dan bobot 100 biji. Data dianalisis dengan analisis ragam dan dilanjutkan dengan uji jarak berganda Duncan (Duncan's Multiple Range Test). Hasil penelitian menunjukkan jenis pupuk kandang mampu meningkatkan tinggi tanaman, jumlah daun, jumlah polong, berat polong dan bobot 100 biji. Peningkatan konsentrasi PGPR hanya meningkatkan tinggi tanaman. Tidak menunjukkan adanya interaksi antara jenis pupuk kandang dan konsentrasi PGPR dalam meningkatkan pertumbuhan dan produksi kedelai hitam.
\end{abstract}

Kata kunci : pupuk kandang ayam, pupuk kandang kambing, PGPR, kedelai hitam

\begin{abstract}
This aims of the experience was to examine the effect of the use of manure types and various concentrations of plant growth-promoting rhizobacteria (PGPR) on the growth and production of black soybean (Glycine max L. Merill). The experimental design was used a completely randomized design of factorial patterns. The first factor was the type of manure (without fertilizer, chicken manure, and goat manure) and the second factor was the concentration of PGPR (commercial PGPR $5 \mathrm{ml} / 1$ water, $0 \mathrm{ml} / 1$ water, $5 \mathrm{ml} / 1$ water, $12.5 \mathrm{ml} / 1$ water, and $20 \mathrm{ml} / \mathrm{l}$ water). Growth parameters observed included plant height and number of leaves. Production parameters observed were the number of pods, pod weight and weight of 100 seeds. Data were analyzed by analysis of variance and followed by Duncan's multiple range test. The results showed the type of manure can increase plant height, number of leaves, number of pods, pod weight and weight of 100 seeds. Increasing the concentration of PGPR only increases plant height. Did not show any interaction between types of manure and PGPR concentrations in increasing the growth and production of black soybeans.
\end{abstract}

Keywords: chicken manure, goat manure, PGPR, black soybean 


\section{PENDAHULUAN}

Kedelai merupakan salah satu tanaman sumber protein penting di Indonesia. Kedelai dalam bidang pangan digunakan sebagai bahan pembuatan tempe, tahu, kecap, susu kedelai, tauco dan makanan ringan. Kebutuhan kedelai di Indonesia pada tahun 2016 mencapai 2,2 juta ton/tahun, sedangkan produksi kedelai pada tahun 2016 sebesar 887,54 ribu ton/tahun. Kebutuhan kedelai yang jauh lebih tinggi jika dibandingkan dengan jumlah produksi di Indonesia menyebabkan munculnya kebijakan pemerintah untuk mengimpor kedelai. Besarnya impor kedelai mencapai 1,6 juta ton/tahun (Kementan, 2016).

Budidaya kedelai hitam tidak terlepas dari kegiatan pemupukan sebagai upaya penyediaan unsur hara untuk menunjang pertumbuhan dan produksi. Sumber pupuk yang dapat digunakan dan ketersediannya melimpah di kalangan masyarakat yaitu pupuk kandang (pukan) ayam, dan pukan kambing. Pupuk kandang tidak hanya mengandung unsur makro seperti nitrogen $(\mathrm{N})$, fosfat $(\mathrm{P})$ dan kalium $(\mathrm{K})$, namun pupuk kandang juga mengandung unsur mikro seperti kalsium $(\mathrm{Ca})$, magnesium $(\mathrm{Mg})$, dan mangan $(\mathrm{Mn})$ yang dibutuhkan tanaman serta berperan dalam memelihara keseimbangan hara dalam tanah, karena pupuk kandang berpengaruh untuk jangka waktu yang lama dan merupakan gudang makanan bagi tanaman (Andayani dan Sarido, 2013). Berdasarkan penelitian sebelumnya dapat diketahui bahwa pupuk kandang kambing memiliki tekstur dengan butiran yang lebih halus dibandingkan dengan pupuk kandang ayam dan pupuk kandang sapi sehingga lebih cepat terdekomposisi. Pupuk dengan tekstur yang halus akan dengan cepat menyediakan unsur hara bagi pertumbuhan tanaman (Myrna et al., 2013). Pupuk kandang memiliki sifat tidak cepat tersedia bagi tanaman sehingga untuk memaksimalkannya dapat menggunakan agen hayati yang mengandung mikroorganisme baik bagi tanaman. Plant growth promoting rhizobacteria (PGPR) atau rhizobakteria pemicu pertumbuhan tanaman (RPPT) ialah kelompok mikroorganisme tanah yang menguntungkan. Bakteri ini diketahui aktif mengkolonisasi di daerah akar tanaman dan memiliki 3 peran utama bagi tanaman (1) sebagai pemacu/perangsang pertumbuhan (biostimulan) dengan mensintesis dan mengatur konsentrasi berbagai zat pengatur tumbuh (fitohormon) seperti IAA, giberelin, sitokinin dan etilen dalam lingkungan akar; (2) sebagai penyedia hara (biofertilizer) dengan mengikat $\mathrm{N}_{2}$ dari udara secara asimbiosis dan melarutkan unsur hara $\mathrm{P}$ yang terikat di dalam tanah; (3) sebagai pengendali patogen yang berasal dari tanah (bioprotectans) dengan cara menghasilkan berbagai senyawa atau metabolit anti pathogen seperti siderophore, $\beta-1,3-$ glukanase, kitinase, antibiotik dan sianida (Damanik dan Suryanto, 2018). Konsentrasi PGPR $12,5 \mathrm{ml} / 1$ memberikan pengaruh nyata pada tanaman kacang tanah dengan parameter pertambahan tinggi tanaman pada fase vegetatif (15 HST sampai $30 \mathrm{HST}$ ), pertambahan tinggi tanaman pada stadium pembentukan polong (30 HST sampai 45 HST), umur berbunga rata-rata, berat basah polong per rumpun, berat kering polong per rumpun, bobot 100 butir benih, dan produksi polong kering per hektar dibanding perlakuan PGPR dengan konsentrasi 7,5 ml/l dan $10 \mathrm{ml} / \mathrm{l}$ (Marom et al., 2017). Jenis pupuk kandang yang digunakan untuk budidaya tanaman kedelai hitam dapat berpengaruh terhadap ketersediaan unsur hara selama fase pertumbuhan hingga panen. Penentuan konsentrasi PGPR sangat diperlukan agar teknik budidaya tanaman kedelai hitam dapat lebih optimal.

Penelitian ini bertujuan untuk mengkaji pengaruh jenis pupuk kandang, konsentrasi PGPR, serta interaksi antara jenis pupuk kandang dan konsentrasi PGPR terhadap pertumbuhan dan produksi kedelai hitam.

\section{METODE PENELITIAN}

Penelitian dilaksanakan pada tanggal 1 Mei - 10 Juli 2019 di Screen House Balai Pengkajian Teknologi Pertanian Jawa Tengah. Analisis materi dan hasil penelitian di lakukan di Laboratorium Ekologi dan Produksi Tanaman Fakultas Peternakan dan Pertanian Universitas Diponegoro, Semarang. Bahan yang digunakan dalam penelitian yaitu benih kedelai hitam varietas detam 
4 prida, PGPR komersial yang diproduksi oleh Wijaya Agro Pratama, pupuk kandang ayam, pupuk kandang kambing, bahan pembuatan biang PGPR (akar bambu), bahan perbanyakan PGPR (biang PGPR, air sebanyak 15 liter, 200 gram bekatul, 200 gram gula pasir, terasi 3 gram, dan 1 sendok kapur sirih), bahan analisis nitrogen, fosfor, kalium, pH. Alat yang digunakan yaitu, thermohydrometer, lux radiation, flamefotometer, spektrofotometer.

Penelitian dilaksanakan menggunakan Rancangan Acak Lengkap (RAL) pola faktorial 3 x 5 dengan 3 kali ulangan. Faktor pertama adalah jenis pupuk kandang dengan 3 taraf perlakuan, yaitu A0 : tanpa pupuk, A1 : pupuk kandang ayam, dan A2 : pupuk kandang kambing. Faktor kedua adalah konsentrasi PGPR dengan 5 taraf perlakuan, yaitu B0 : PGPR komersial $5 \mathrm{ml} / \mathrm{l}$ air, B1 : $0 \mathrm{ml} / \mathrm{l}$ air, B2 : $5 \mathrm{ml} / \mathrm{l}$ air, B3 : 12,5 ml/l air, dan B4 : $20 \mathrm{ml} / \mathrm{l}$ air. Kombinasi perlakuan sebanyak 15 dengan 3 kali ulangan. Data yang diperoleh kemudian dianalisis dengan analisis ragam untuk mengetahui pengaruh perlakuan dan dilanjutkan dengan uji jarak berganda Duncan (Duncan's Multiple Range Test) pada taraf 5\%.

Prosedur penelitian dilakukan melalui dua tahap yaitu tahap persiapan dan pelaksanaan. Tahap persiapan dilakukan pembuatan biang PGPR lalu perbanyakan PGPR, analisis kadar N, P, $\mathrm{K}, \mathrm{C}$-organik tanah dan pupuk kandang (Tabel 1). Media yang digunakan adalah campuran tanah dan sekam dengan oerbandingan $2: 1$. Tanah berasal dari lahan sekitar Screen House Balai Pengkajian Teknologi Pertanian Jawa Tengah pada kedalaman
1-20 $\mathrm{cm}$ dengan $\mathrm{pH}$ 6,5. Tanah sebanyak $7 \mathrm{~kg}$ dimasukkan kedalam polybag berukuran 35 x 35 $\mathrm{cm}$ dan dicampur dengan sekam. Pembuatan media tanam dilakuakan 1 minggu sebelum tanam, yaitu dengan cara polybag diisi tanah dan sekam kemudian ditambah dengan pupuk kandang sesuai dengan perlakuan.Perlakuan PGPR dengan cara melarutkan PGPR sesuai dengan konsentrasi dalam 1 liter air. Larutan PGPR diambil sebanyak $250 \mathrm{ml}$ dan kemudian disiramkan ke masingmasing polybag pada 7, 14, 21 dan 28 HST. Perawatan dilakukan dengan pemasangan ajir berupa bilah bambu setinggi $1,5 \mathrm{~m}$ di dekat tanaman yang dilakukan pada 20 hari setelah tanam (HST). Pengamatan dilakukan hingga tanaman siap panen yaitu saat tanaman berumur sepuluh minggu setelah tanam.

Parameter penelitian meliputi : (1) Tinggi tanaman, diukur dari pangkal batang sampai titik tumbuh tanaman (tunas) menggunakan meteran mulai umur 1 MST. (2) Jumlah daun, dihitung jumlah daun yang terbuka sempurna pada setiap unit percobaan. (3) Jumlah polong, dihitung jumlah polong per tanaman. (4) Berat polong dihitung dengan cara menimbang polong setiap unit percobaan dengan menggunakan timbangan analitik. (5) Bobot 100 biji dihitung menggunakan rumus :

Bobot 100 biji $=\frac{\text { Berat biji per tanaman }}{\text { Jumlah biji per tanamar. }} \times 100$

Tabel 1. Hasil Analisis Kadar Hara Tanah dan Pupuk Kandang

\begin{tabular}{lcccccc}
\hline Jenis & $\begin{array}{c}\mathrm{N} \\
(\%)\end{array}$ & $\begin{array}{c}\mathrm{P}_{2} \mathrm{O}_{5} \\
(\%)\end{array}$ & $\begin{array}{c}\mathrm{K}_{2} \mathrm{O} \\
(\%)\end{array}$ & $\begin{array}{c}\text { C-Organik } \\
(\%)\end{array}$ & $\mathrm{BO}$ & $\mathrm{C} / \mathrm{N}$ \\
\hline Tanah & 0,10 & 0,09 & 0,02 & 1,72 & 3 & 18 \\
Pupuk Kandang Ayam & 1,36 & 2,48 & 1,41 & 33,11 & 57 & 24 \\
Pupuk Kandang Kambing & 1,21 & 1,14 & 0,42 & 24,75 & 42 & 20 \\
\hline
\end{tabular}

\section{HASIL DAN PEMBAHASAN}

\section{Tinggi Tanaman}

Hasil uji jarak berganda Duncan (UJBD) perlakuan berbagai jenis pupuk kandang dan konsentrasi PGPR pada tinggi tanaman disajikan pada Tabel 2. Hasil uji jarak berganda Duncan menunjukkan bahwa rata-rata tinggi tanaman terbaik terdapat pada perlakuan jenis pupuk kandang (pukan) kambing. Bentuk pukan kambing yang lebih halus dari pukan ayam menjadikan 
pukan kambing lebih cepat terdekomposisi dan tersedia bagi tanaman. Hal ini sesuai dengan pendapat Myrna et al. (2013) yang menyatakan bahwa pupuk kandang kambing memiliki tekstur dengan butiran yang lebih halus dibandingkan dengan pupuk kandang ayam dan pupuk kandang sapi sehingga lebih cepat terdekomposisi. Pupuk dengan tekstur yang halus akan dengan cepat menyediakan unsur hara bagi pertumbuhan tanaman. Kecepatan penyerapan unsur hara oleh tanaman dipengaruhi oleh kecepatan proses dekomposisi (Prasetyo, 2014).

Tabel 2. Tinggi Tanaman Kedelai Hitam (Glycine max L. Merill) pada Berbagai Jenis Pupuk Kandang dan Konsentrasi PGPR

\begin{tabular}{ccccccc}
\hline Perlakuan & B0 & B1 & B2 & B3 & B4 & Rata-rata \\
\hline A0 & 53,35 & 47,17 & 49,56 & 50,74 & 54,00 & $50,96^{\mathrm{c}}$ \\
A1 & 58,63 & 53,42 & 54,82 & 57,85 & 58,99 & $56,74^{\mathrm{b}}$ \\
A2 & 61,01 & 55,88 & 59,55 & 60,43 & 62,32 & $59,84^{\mathrm{a}}$ \\
\hline Rata-rata & $57,66^{\text {ab }}$ & $52,16^{\mathrm{c}}$ & $54,64^{\mathrm{bc}}$ & $56,34^{\mathrm{ab}}$ & $58,44^{\mathrm{a}}$ &
\end{tabular}

Keterangan: Superskrip berbeda pada kolom dan baris menunjukkan perbedaan yang nyata $(\mathrm{p}<0,05)$. A0 $=\operatorname{tanpa}$ pupuk kandang, $\mathrm{A} 1=$ pupuk kandang ayam, $\mathrm{A} 2=$ pupuk kandang kambing, $\mathrm{B} 0=$ PGPR komersial $5 \mathrm{ml} / 1$ air, $\mathrm{B} 1=$ $0 \mathrm{ml} / \mathrm{l}$ air, B2 $=5 \mathrm{ml} / \mathrm{l}$ air, B3 $=12,5 \mathrm{ml} / \mathrm{l}$ air, B4 $=20 \mathrm{ml} / \mathrm{l}$ air.

Perlakuan pemberian konsentrasi PGPR 20 $\mathrm{ml} / 1$ air memberikan hasil tinggi tanaman terbaik yang berbeda nyata dengan tanpa pemberian PGPR dan pemberian konsentrasi PGPR $5 \mathrm{ml} / 1$ air. Pemberian konsentrasi PGPR $20 \mathrm{ml} / 1$ air tidak berbeda nyata dengan pemberian PGPR dengan konsentrasi 12,5 ml/1 air dan PGPR komersial 5 $\mathrm{ml} / \mathrm{l}$ air. Pemberian konsentrasi PGPR $5 \mathrm{ml} / \mathrm{l}$ air tidak berbeda nyata dengan pemberian PGPR 12,5 $\mathrm{ml} / \mathrm{l}$ air, PGPR komersial $5 \mathrm{ml} / \mathrm{l}$ air dan tanpa PGPR. Hal ini menunjukkan bahwa pemberian PGPR dengan konsentrasi $5 \mathrm{ml} / 1$ air sudah mampu memberikan hasil yang baik pada pertumbuhan tinggi tanaman kedelai hitam. Hasil penelitian juga mengindikasikan bahwa konsentrasi PGPR 5 ml/l air yang dibuat sendiri sudah mampu mengimbangi PGPR komersial $5 \mathrm{ml} / \mathrm{l}$ air. Hal tersebut diduga karena PGPR yang digunakan dalam penelitian mensintesis hormon auksin dan giberelin. Auksin dan giberelin terdapat pada embrio dan meristem apikal dan berfungsi untuk pemanjangan sel sehingga kedua hormon inilah yang diduga telah memberikan pengaruh terhadap tinggi tanaman (Iswati, 2012).

\section{Jumlah Daun}

Hasil uji jarak berganda Duncan (UJBD) perlakuan berbagai jenis pupuk kandang dan konsentrasi PGPR pada jumlah daun disajikan pada Tabel 3. Hasil uji jarak berganda Duncan menunjukkan bahwa rata-rata jumlah daun terbaik terdapat pada perlakuan jenis pupuk kandang (pukan) kambing. Pukan kambing yang digunakan dalam penelitian memiliki nilai $\mathrm{C} / \mathrm{N}$ yang lebih rendah dibandingkan dengan pukan ayam yaitu sebesar 20 yang mendekati nilai $\mathrm{C} / \mathrm{N}$ rasio tanah. Nilai $\mathrm{C} / \mathrm{N}$ rasio yang mendekati tanah lebih mudah diserap oleh tanaman. Hal tersebut sesuai dengan penyataan Sitompul et al. (2017) yang menyebutkan bahwa bahan organik yang mempunyai kandungan $\mathrm{C} / \mathrm{N}$ mendekati atau sama dengan $\mathrm{C} / \mathrm{N}$ tanah yaitu 10-20 maka bahan tersebut dapat digunakan atau diserap tanaman. Nilai $\mathrm{C} / \mathrm{N}$ mempengaruhi ketersediaan $\mathrm{N}$ yang mempengaruhi pertumbuhan vegetatif tanaman seperti tinggi tanaman dan jumlah daun. Arifah (2013) menyatakan bahwa ketersediaan unsur hara dipengarui oleh nisbah $\mathrm{C} / \mathrm{N}$. Pupuk kandang yang mempunyai nisbah $\mathrm{C} / \mathrm{N}$ tinggi berarti secara relatif mengandung lebih banyak $\mathrm{C}$ daripada $\mathrm{N}$ pada tanah, maka akan ada persaingan nitrogen antara tanaman dengan mikroorganisme, akan ada sumber energi yang banyak dan mikroorganisme akan menggunakan nitrogen yang ada untuk pembentukan dan perkembangannya. Nitrogen tersebut diikat pada tubuh mikroorganisme dan akan kurang tersedia didalam tanah. Jika proses nitrifikasi berjalan dengan baik, maka nisbah $\mathrm{C} / \mathrm{N}$ akan rendah dan hal ini mencirikan bahwa pupuk 
kandang telah terdekomposisi dengan baik, dengan demikian pupuk kandang sudah tersedia bagi pertumbuhan dan perkembangan tanaman. Pemberian perlakuan berbagai konsentrasi

PGPR serta pemberian perlakuan jenis pupuk kandang dan peningkatan konsentrasi PGPR tidak berbeda nyata terhadap jumlah daun kedelai hitam. Hal tersebut karena PGPR yang digunakan dalam penelitian tidak mengandung bakteri penambat $\mathrm{N}$ sehingga peran PGPR dalam pertumbuhan tidak berjalan dengan baik. Hal ini sejalan dengan penelitian Febriyanti et al. (2015) yang menyatakan bahwa PGPR tidak mampu meningkatkan jumlah daun pada tanaman kacang tanah.

Tabel 3. Jumlah Daun Tanaman Kedelai Hitam (Glycine max L. Merill) pada Berbagai Jenis Pupuk Kandang dan Konsentrasi PGPR

\begin{tabular}{crrrrrr}
\hline Perlakuan & B0 & B1 & \multicolumn{1}{c}{ B2 } & \multicolumn{1}{c}{ B3 } & B4 & Rata-rata \\
\hline A0 & 5,33 & 6,00 & 6,00 & 6,33 & 6,00 & $5,93^{\mathrm{c}}$ \\
A1 & 7,33 & 8,00 & 7,67 & 7,00 & 8,00 & $7,6^{\mathrm{b}}$ \\
A2 & 8,33 & 8,33 & 8,67 & 8,33 & 8,00 & $8,33^{\mathrm{a}}$ \\
\hline Rata-rata & 57,66 & 52,16 & 54,64 & 56,34 & 57,66 & \\
\hline
\end{tabular}

Keterangan: Superskrip berbeda pada kolom dan baris menunjukkan perbedaan yang nyata $(p<0,05)$. A0 $=$ tanpa pupuk kandang, $\mathrm{A} 1=$ pupuk kandang ayam, $\mathrm{A} 2=$ pupuk kandang kambing, $\mathrm{B} 0=$ PGPR komersial $5 \mathrm{ml} / \mathrm{l}$ air, B1 = $0 \mathrm{ml} / \mathrm{l}$ air, B2 $=5 \mathrm{ml} / \mathrm{l}$ air, B3 $=12,5 \mathrm{ml} / \mathrm{l}$ air, B4 $=20 \mathrm{ml} / \mathrm{l}$ air.

\section{Jumlah Polong}

Hasil uji jarak berganda Duncan (UJBD) perlakuan berbagai jenis pupuk kandang dan konsentrasi PGPR pada jumlah polong disajikan pada Tabel 4. Hasil uji jarak berganda Duncan menunjukkan bahwa rata-rata jumlah polong terbaik terdapat pada perlakuan jenis pupuk kandang (pukan) ayam yang tidak berbeda nyata dengan pukan kambing namun berbeda nyata dengan perlakuan tanpa diberi pupuk kandang. Pemberian pupuk kandang pada tanah menambah unsur hara mikro dan makro yang dapat menunjang perkembangan tanaman. Penggunaan pupuk kandang dapat memperbaiki kesuburan tanah, permeabilitas tanah, porositas tanah, struktur tanah, daya menahan air dan kandungan kation tanah, sehingga mempercepat pertumbuhan tanaman (Zainal et al., 2014).

Tabel 4. Jumlah Polong Tanaman Kedelai Hitam (Glycine max L. Merill) pada Berbagai Jenis Pupuk Kandang dan Konsentrasi PGPR

\begin{tabular}{ccccccc}
\hline Perlakuan & B0 & B1 & B2 & B3 & B4 & Rata-rata \\
\hline A0 & 18,00 & 18,33 & 18,00 & 19,67 & 22,67 & $19,33^{\mathrm{b}}$ \\
A1 & 45,67 & 40,67 & 41,33 & 44,00 & 41,00 & $42,53^{\mathrm{a}}$ \\
A2 & 43,33 & 42,33 & 44,67 & 40,00 & 43,33 & $42,73^{\mathrm{a}}$ \\
\hline Rata-rata & 35,67 & 33,78 & 34,67 & 34,56 & 35,67 & \\
\hline
\end{tabular}

Keterangan: Superskrip berbeda pada kolom dan baris menunjukkan perbedaan yang nyata (p<0,05). A0 = tanpa pupuk kandang, A1 = pupuk kandang ayam, A2 = pupuk kandang kambing, B0 = PGPR komersial $5 \mathrm{ml} / \mathrm{l}$ air, B1 = $0 \mathrm{ml} / \mathrm{l}$ air, B2 = $5 \mathrm{ml} / \mathrm{l}$ air, B3 = 12,5 ml/1 air, B4 = $20 \mathrm{ml} / \mathrm{l}$ air.

Pemberian perlakuan berbagai konsentrasi PGPR serta pemberian perlakuan jenis pupuk kandang dan peningkatan konsentrasi PGPR tidak berbeda nyata terhadap jumlah polong. Hal tersebut diduga karena PGPR yang digunakan tidak dapat melarutkan unsur hara P yang terdapat pada pupuk kandang. Unsur hara $\mathrm{P}$ dapat mengaktifkan pembentukan polong dan pengisian polong yang masih kosong, serta mempercepat pemasakan buah (Silalahi, 2009). Hasil penelitian serupa juga dialami oleh Marom et al. (2017) yang menyatakan bahwa pemberian PGPR tidak 
berpengaruh terhadap jumlah polong per rumpun pada kacang tanah.

\section{Berat Polong}

Hasil uji jarak berganda Duncan (UJBD) perlakuan berbagai jenis pupuk kandang dan konsentrasi PGPR pada berat polong disajikan pada Tabel 5. Hasil uji jarak berganda Duncan menunjukkan bahwa rata-rata berat polong terbaik terdapat pada perlakuan jenis pupuk kandang (pukan) ayam. Hal tersebut dikarenakan pupuk kandang ayam memiliki kandungan unsur hara $\mathrm{P}$ lebih tinggi dibandingkan pukan kambing. Pukan ayam yang digunakan dalam penelitian mengandung unsur hara $\mathrm{P}$ sebesar $2,48 \%$ sedangkan pukan kambing mengandung unsur hara $\mathrm{P}$ sebesar $1,14 \%$. Unsur hara $\mathrm{P}$ sangat berperan dalam pertumbuhan generatif tanaman. Peran $P$ yang diserap tanaman antara lain penting untuk pertumbuhan sel, pembentukan akar halus dan rambut akar, memperkuat tanaman agar tidak mudah rebah, memperbaiki kualitas tanaman, pembentukan bunga, buah dan biji serta memperkuat daya tahan terhadap serangan penyakit, sehingga jumlah polong isi akan semakin kuat (Kurniawan et al., 2014).

Pemberian perlakuan berbagai konsentrasi PGPR serta pemberian perlakuan jenis pupuk kandang dan peningkatan konsentrasi PGPR tidak berbeda nyata terhadap berat polong. Hal tersebut terjadi diduga karena bakteri PGPR yang digunakan dalam penelitian tidak dapat melarutkan unsur hara $\mathrm{P}$. Unsur hara $\mathrm{P}$ digunakan untuk membentuk ATP pada tanaman sebagai energi dalam proses fotosintesis sehingga apabila ATP tercukupi maka proses fotosintesis akan berjalan dengan baik dan hasil fotosintesis meningkat sehingga pembentukan polong optimal (Arista $e t$ al., 2015).

Tabel 5. Berat Polong Tanaman Kedelai Hitam (Glycine max L. Merill) pada Berbagai Jenis Pupuk Kandang dan Konsentrasi PGPR

\begin{tabular}{ccccccc}
\hline Perlakuan & B0 & B1 & B2 & B3 & B4 & Rata-rata \\
\hline A0 & 6,45 & 7,11 & 7,92 & 7,45 & 9,19 & $7,62^{\text {c }}$ \\
A1 & 23,07 & 21,99 & 17,54 & 26,84 & 21,46 & $22,18^{\text {a }}$ \\
A2 & 18,49 & 19,92 & 17,16 & 17,56 & 20,22 & $18,67^{\mathrm{b}}$ \\
\hline Rata-rata & 16,00 & 16,34 & 14,21 & 17,28 & 16,95 & \\
\hline
\end{tabular}

Keterangan: Superskrip berbeda pada kolom dan baris menunjukkan perbedaan yang nyata $(p<0,05)$. A0 $=$ tanpa pupuk kandang, $\mathrm{A} 1=$ pupuk kandang ayam, $\mathrm{A} 2=$ pupuk kandang kambing, $\mathrm{B} 0=$ PGPR komersial $5 \mathrm{ml} / \mathrm{l}$ air, $\mathrm{B} 1=$ $0 \mathrm{ml} / \mathrm{l}$ air, B2 $=5 \mathrm{ml} / \mathrm{l}$ air, B3 $=12,5 \mathrm{ml} / \mathrm{l}$ air, B4 $=20 \mathrm{ml} / \mathrm{l}$ air.

\section{Berat 100 Biji}

Hasil uji jarak berganda Duncan (UJBD) perlakuan berbagai jenis pupuk kandang dan konsentrasi PGPR pada berat 100 biji disajikan pada tabel 6. Hasil uji jarak berganda Duncan menunjukkan bahwa rata-rata bobot 100 biji terbaik terdapat pada perlakuan jenis pupuk kandang (pukan) ayam yang tidak berbeda nyata dengan pukan kambing namun berbeda nyata dengan perlakuan tanpa diberi pupuk kandang. Pupuk kandang merupakan bahan pembenah tanah yang lebih baik daripada bahan pembenah buatan, walaupun pada umumnya pupuk kandang mempunyai kandungan hara makro $\mathrm{N}, \mathrm{P}$ dan $\mathrm{K}$ yang rendah tetapi mengandung hara mikro dalam jumlah cukup yang sangat diperlukan dalam pertumbuhan tanaman (Nurlenawati et al., 2010).

Pemberian perlakuan berbagai konsentrasi PGPR serta pemberian perlakuan jenis pupuk kandang dan peningkatan konsentrasi PGPR tidak berbeda nyata terhadap bobot 100 biji. Hal tersebut diduga karena bakteri PGPR tidak mampu melarutkan unsur hara $\mathrm{P}$ dan tidak dapat meningkatkan ketersediaan unsur hara K. Hal ini bearti PGPR tidak mempengaruhi adanya penambahan bobot biji pada tanaman kedelai (Putri et al., 2013). 
Tabel 6. Bobot 100 Biji Tanaman Kedelai Hitam (Glycine max L. Merill) pada Berbagai Jenis Pupuk Kandang dan Konsentrasi PGPR

\begin{tabular}{ccccccc}
\hline Perlakuan & B0 & B1 & B2 & B3 & B4 & Rata-rata \\
\hline A0 & 11,16 & 11,40 & 12,73 & 10,10 & 12,95 & $11,67^{\mathrm{b}}$ \\
A1 & 15,52 & 15,65 & 13,09 & 14,88 & 15,82 & $14,99^{\mathrm{a}}$ \\
A2 & 13,38 & 13,48 & 12,20 & 13,80 & 15,29 & $13,63^{\mathrm{a}}$ \\
\hline Rata-rata & 13,36 & 13,51 & 12,67 & 12,93 & 14,69 & \\
\hline
\end{tabular}

Keterangan: Superskrip berbeda pada kolom dan baris menunjukkan perbedaan yang nyata (p<0,05). A0 = tanpa pupuk kandang, A1 = pupuk kandang ayam, A2 = pupuk kandang kambing, B0 = PGPR komersial 5 ml/1 air, B1= $0 \mathrm{ml} / \mathrm{l}$ air, B2 = $5 \mathrm{ml} / \mathrm{l}$ air, B3 = 12,5 ml/l air, B4 = $20 \mathrm{ml} / \mathrm{l}$ air.

\section{KESIMPULAN}

Berdasarkan penelitian yang telah dilaksanakan maka dapat disimpulkan bahwa jenis pukan kambing mampu meningkatkan tinggi tanaman dan jumlah daun lebih tinggi dibanding pukan ayam, namun pukan ayam mampu meningkatkan berat polong lebih tinggi dibandingkan pukan kambing. Kedua pupuk kandang mampu meningkatkan berat polong dan berat 100 biji. Peningkatan konsentrasi PGPR tidak berpengaruh pada pertumbuhan dan produksi tanaman kedelai hitam kecuali pada tinggi tanaman. Tidak menunjukkan adanya interaksi antara jenis pupuk kandang dan konsentrasi PGPR pada seluruh variabel pengamatan.

\section{DAFTAR PUSTAKA}

Andayani, dan L. Sarido. 2013. Uji empat jenis pupuk kandang terhadap pertumbuhan dan hasil tanaman cabai keriting (Capsicum annum L.). J. Agrifor. 12 (1) : $22-29$.

Anesta, D.O., I. D. N. Nyana, adan A. A. M. Astiningsih. 2016. Studi hasil dan kualitas benih padi P05 dengan pemberian pupuk hayati (Enterobacter cloacae). J. Tropical Agroecotechnology. 5 (2) : 116- 126.

Arista, D., Suryono, dan Sudadi. 2015. Efek dari kombinasi pupuk $\mathrm{N}$, $\mathrm{P}$, dan $\mathrm{K}$ terhadap pertumbuhan dan hasil kacang tanah pada lahan kering Alfisol. J. Agrosains. 17 (2) : $49-52$.

Arifah, S. M. 2013. Aplikasi macam dan dosis pupuk kandang pada tanaman kentang. J. Gamma. 8 (2) : $80-85$.
Damanik, S. A., dan A. Suryanto. 2018. Efektivitas penggunaan mikoriza dan PGPR (plant growth promoting rhizobacteria) terhadap tanaman bawang merah (Allium ascalonicum L.) pada pipa PVC sistem vertikultur. J. Produksi Tanaman. 6 (4) : 635 -641 .

Febriyanti, L. E., M. Martosudiro, dan T. Hadiastono. 2015. Pengaruh plant growth promoting rhizobacteria (PGPR) terhadap infeksi peanut stripe virus (PSTV), pertumbuhan dan produksi tanaman kacang tanah (Arachis hypogaea L.) varietas gajah. J. HPT. 3 (1) : 84 - 93.

Irwan, A. W., dan T. Nurmala. 2018. Pengaruh pupuk hayati majemuk dan pupuk fosfor terhadap pertumbuhan dan hasil kedelai di inceptisol Jatinangor. J. Kultivasi. 17 (3) $750-759$.

Iswati, R. 2012. Pengaruh dosis formula PGPR asal perakaran bambu terhadap pertumbuhan tanaman tomat (Solanum lycopersicum). JATT. 1 (1) : 9 - 12.

Kementerian Pertanian. 2016. Komoditas Pertaninan Sub Sektor Tanaman Pangan Kedelai. Direktorat Jenderal Tanaman Pangan. Jakarta.

Kurniawan, Shandy., Aslim Rasyad., dan Wardati. 2014. Pengaruh pemberian pupuk posfor terhadap pertumbuhan beberapa varietas kedelai (Glycine $\max$ (L.) Merril). J. Faperta.1 (2) : 1-11.

Marom, N., Rizal, R., dan M. Bintoro. 2017. Uji efektivitas waktu pemberian dan konsentrasi PGPR (Plant Growth Promoting Rhizobacteria) terhadap produksi dan mutu 
benih kacang tanah (Arachis hypogaea L.). J. Agriprima. 1 (2) : 191 - 202.

Myrna, N. E., F. B. Ichwan, dan H. Salim. 2013. Pertumbuhan dan hasil dua varietas kedelai (Glycine max L. Merril) pada perbedaan pupuk organik. J. Produksi Tanaman. 2 (1) : $40-47$.

Nurlenawati, N., A. Jannah, dan Nimih. 2014. Respon pertumbuhan dan hasil tanaman cabai merah (Capsicum annuum L.) varietas prabu terhadap berbagai dosis pupuk fosfat dan bokashi jerami limbah jamur merang. J. Agrika. 4 (1) : $9-20$.

Prasetyo, R. 2014. Pemanfaatan berbagai sumber pupuk kandang sebagai sumber dalam budidaya cabai merah (Capsicum annum $\mathrm{L}$.) di Tanah Berpasir. J. Agro Science. 2 (2) : $125-132$.

Sitompul, E., I. W. Wardhana, dan E. Sutrisno. 2017. Studi identifikasi rasio $\mathrm{C} / \mathrm{N}$ pengolahan sampah organik sayuran sawi, daun singkong, dan kotoran kambing dengan variasi komposisi menggunakan metode Vermikomposting. J. Teknik Lingkungan. 6 (2) : $1-12$.

Zainal, M., A. Nugroho, dan N. E. Suminarti. 2014. Respon pertumbuhan dan hasil tanaman kedelai (Glycine max (L.) Merill) pada berbagai tingkat pemupukan $\mathrm{N}$ dan pupuk kandang ayam. J. Produksi Tanaman. $2(6): 484-490$. 